\title{
COLUMN
}

\section{Per ongeluk verbonden}

\author{
Femke Ruitenbeek-Bart
}

Enige tijd geleden las ik een boek met de titel Vergeef niet te snel. ${ }^{1}$ Op de voorkant daarvan prijkte een afbeelding van twee handen. De ene hand is een gebalde vuist, de andere hand een open, uitgestoken hand. De illustratie, passend bij de ondertitel van het boek (De twee helende handen uitstrekken) is gebaseerd op een citaat van Barbara Deming, een Amerikaanse feministe en sterk voorstander van geweldloze sociale verandering:

'Geweldloosheid geeft ons twee handen ten opzichte van de onderdrukker de ene hand om hem af te nemen wat hem niet toekomt, de andere hand om hem daarbij langzaam te kalmeren. De tweede hand nodigt de onderdrukker uit tot bezinning en biedt perspectief op verbinding en mogelijk zelfs op vergeving.'

Voor dit themanummer over verkeer nodigt dit beeld van de twee handen, de gebalde vuist enerzijds en de uitgestoken hand anderzijds, uit tot een reflectie op het verkeersaansprakelijkheidsrecht. Herkennen we daarin die twee handen? Zien we in de juridische omgang met verkeersongevallen de gebalde vuist van een getroffene die opstaat tegen onrecht en de normschender ter verantwoording roept? En zien we daarin ook een uitgestoken hand die verbinding zoekt met de normschender, zodanig dat ook hij (of zij) het ongeval een passende plaats in zijn (of haar) leven kan geven?

\section{De gebalde vuisten van verkeersaansprakelijkheid}

Verkeersaansprakelijkheid kent twee smaken: strafrechtelijke en civielrechtelijke aansprakelijkheid. Deze twee smaken vertegenwoordigen twee belangrijke functies van aansprakelijkheid: vergelden en vergoeden. In het vergeldende strafrecht is overduidelijk de gebalde vuist te herkennen: bij voldoende ernstige verwijtbaarheid kan de ongevalsveroorzaker gestraft worden met een boete, een taakstraf of soms zelfs een gevangenisstraf. In het civiele recht heeft die vuist de gedaante van een schadevergoedingsplicht: de veroorzaker moet de aan het verkeersslachtoffer toegebrachte schade vergoeden. Beide rechtsgangen maken een vuist en roepen de veroorzaker ter verantwoording.

1 D. Linn \& S. Linn-Fabricant, Vergeef niet te snel, Franeker: Uitgeverij Van Wijnen 2007. Oorspronkelijke titel: Don't forgive too soon - Extending the two hands that heal (vert. T. YürümezKroon). 
De uitgestoken hand is in deze klassieke rechtsgangen vaak moeilijker te herkennen. Beide rechtspraktijken zijn tegensprekelijk van aard en lijken vooral de dichotomie tussen het verkeersslachtoffer en de ongevalsveroorzaker te benadrukken. Voor de ongevalsbetrokkenen werkt het aansprakelijkheidsrecht, of het nu gaat om de strafrechtelijke of de civielrechtelijke variant, eerder polariserend dan verbindend. Die polarisatie wordt versterkt doordat beide rechtsgangen zodanig zijn ingericht, dat het oorspronkelijke conflict losgezongen raakt van de belangrijkste betrokkenen: het verkeersslachtoffer en de ongevalsveroorzaker.

\section{Verbinding in het vergeldende strafrecht?}

In het strafrecht staat de schijnwerper gericht op de ongevalsveroorzaker. Maar omdat het vervolgingsmonopolie bij het Openbaar Ministerie (OM) ligt, staat het slachtoffer op afstand. Wel heeft het slachtoffer zich een steeds betere procespositie weten te verwerven. Als deze emancipatie van slachtoffers van strafbare feiten - waaronder ook verkeersslachtoffers - iets duidelijk maakt, dan is het wel hoezeer een verkeersslachtoffer er belang aan hecht actief betrokken te worden bij en gehoord te worden in de strafrechtelijke afdoening van 'zijn' verkeersongeval. Maar de praktijk is weerbarstig; in de kern blijft het strafproces vooral een proces tussen (vermeende) dader en OM.

Op dit punt biedt restorative justice een waardevolle aanvulling op het klassieke strafrecht. Restorative justice zet nadrukkelijk in op actieve betrokkenheid en verantwoordelijkheid van alle betrokkenen gezamenlijk: slachtoffer, dader én gemeenschap. Restorative justice is bovendien gericht op een meer holistische vorm van herstel van onrecht: herstel omvat niet alleen financieel herstel, maar ook persoonlijk herstel, bijvoorbeeld van het geschonden zelfbeeld. Ook relationeel herstel, herstel tussen normschender en getroffene, maar ook in relatie tot de getroffen gemeenschap(pen), krijgt een plaats. En zo steekt restorative justice twee helende handen uit: het helpt getroffenen een vuist te maken tegen ervaren onrecht, maar met een uitgestoken hand naar de normschender.

\section{Verbinding in het vergoedende civiele recht?}

Kijken we naar de civiele rechtsgang, die gericht is op vergoeding van geleden schade, dan zien we de ongevalsbetrokkenen in een heel andere rolverdeling. Een eerste belangrijk verschil is dat de civiele letselschadepraktijk juist slachtoffergericht is. Wat verder opvalt, is dat de veroorzaker geen rol van noemenswaardige betekenis speelt in de civielrechtelijke afdoening van de gevolgen van het door hem veroorzaakte ongeval. Een overeenkomst met de strafrechtelijke rechtsgang is dat een andere dominante partij het speelveld betreedt, alleen is dat in civilibus niet het OM, maar de aansprakelijkheidsverzekeraar van de ongevalsveroorzaker. In termen van vergoeding is het bestaan van verzekering van verkeersaansprakelijkheid, die voor motorrijtuigen zelfs wettelijk verplicht is, ontegenzeggelijk een verworvenheid. Maar die 'verzekerde verkeersaansprakelijkheid' impliceert ook 
een overheveling van het conflict naar de schaderegelingsverhouding tussen het verkeersslachtoffer en de verzekeraar. De veroorzaker, een belangrijke betrokkene, verdwijnt goeddeels uit het zicht, want in discussies over aansprakelijkheid en schadeomvang heeft de aansprakelijke veroorzaker in de regel niet zoveel in te brengen. Het is zoals een claimbehandelaar mij eens zei: 'De verzekerde is aansprakelijk, dat is voor ons voldoende informatie.' Ook het civiele conflict raakt dus losgezongen van een van de belangrijkste betrokkenen. De verzekeraar betreedt het toneel; de veroorzaker verdwijnt uit beeld.

Zo'n afwezige veroorzaker is vanuit het systeem van verzekerde aansprakelijkheid goed te verklaren. Uit het oogpunt van restorative justice is het wel problematisch, want noch de gebalde vuist, noch de uitgestoken hand komt zo goed tot zijn recht. De vraag is zelfs gerechtvaardigd of de ongevalsveroorzaker de gebalde vuist van het civiele recht überhaupt opmerkt, aangezien de financiële pijn toch afgewenteld wordt op de verzekeraar, en dus op het collectief van verzekerden. Bedenken we daarbij dat de drempel voor strafrechtelijke aansprakelijkheid beduidend hoger ligt dan de drempel voor civiele aansprakelijkheid en dat dus niet iedere ongevalsveroorzaker geconfronteerd wordt met de vergeldende vuist van het strafrecht, dan rijst de vraag waar die ongevalsveroorzakers dan wel ter verantwoording worden geroepen. Maar indachtig het citaat van Deming verdient ook een andere vraag aandacht: waar kunnen ongevalsveroorzakers eigenlijk terecht met hun eigen ongevalservaringen, hun persoonlijke behoeften, zorgen en vragen? Waar treffen zij een uitgestoken hand?

Gelukkig weten sommige ongevalsbetrokkenen, onder wie ook veroorzakers, zelf de weg naar organisaties als Perspectief Herstelbemiddeling te vinden, zo valt ook te lezen in andere bijdragen in dit themanummer. Maar een kleinschalige rondvraag onder claimbehandelaars van verkeersaansprakelijkheidsverzekeraars leerde mij dat deze organisatie in de verzekeringsbranche weinig bekendheid geniet. En dat geeft te denken. Volgens mij zou ook de civiele letselschadepraktijk gebaat zijn bij een meer restoratieve, of misschien zelfs relationele kijk op het aansprakelijkheidsrecht. Anders geformuleerd: het civiele aansprakelijkheidsproces (in brede zin) zou meer oog mogen hebben voor het belang van relational restoration.

\section{Relationeel herstel}

Deze term, relationeel herstel of relational restoration, verdient enige toelichting, zeker in het kader van verkeersaansprakelijkheid. Als ik met andere civilisten spreek over relationeel herstel, krijg ik vaak tegengeworpen dat bij verkeersongevallen (vaak) geen sprake was van een bestaande relatie tussen de ongevalsbetrokkenen. En dat er dus geen relatie was die nu, na het ongeval, om herstel vraagt. Inderdaad was er meestal (maar overigens niet altijd) voor het ongeval geen relatie tussen de latere ongevalsbetrokkenen. Dat neemt niet weg dat in het ongevalsmoment wel een vorm van een relatie ontstaat, zij het een die haar oorsprong vond in het ongeluk. Het slachtoffer en de veroorzaker zijn met en vanwege het 
ongeval geen 'toevallige, anonieme passanten in het verkeer' meer. In dat ongevalsmoment hebben hun levens zich elkaar heel nadrukkelijk en indringend gekruist en beïnvloed. De veel gesignaleerde behoefte van letselschadeslachtoffers, ook van verkeersslachtoffers, aan excuses duidt ook op behoefte aan een vorm van relationeel herstel. De behoefte aan excuses doet immers een appel op de veroorzaker. Wat vaak minder goed zichtbaar wordt, is dat bij ongevalsveroorzakers een spiegelbeeldige behoefte aan relationeel herstel kan leven. Daar lijkt dus een vruchtbare bodem voor relationeel herstel, maar toch komen de beide behoeften van het verkeersslachtoffer en de ongevalsveroorzaker in de praktijk zo moeilijk tot elkaar. Sabine Cocquyt verwoordt het treffend:

'Menslief, wat een kluwen? Wat is het toch moeilijk allemaal: contact of geen contact. De een zucht: ik zou een kaartje willen schrijven. En de ander wil er zo graag een ontvangen, maar het gebeurt niet. Wat zitten we soms naar elkaar te zoeken. Te wachten, te twijfelen, te vrezen. Hoe jammer eigenlijk. Wat een gemiste kansen soms.'

In mijn gesprekken met ongevalsveroorzakers beluister ik dat ook zij behoefte hebben aan contact met het slachtoffer. Om medeleven te kunnen tonen, om 'sorry' te kunnen zeggen, om hun kant van het verhaal te kunnen vertellen. Maar bijvoorbeeld ook om het beeld dat de ander mogelijk van hen heeft, bij te kunnen stellen. Zo zei een van de geïnterviewden: 'Ik zou willen dat zij mij wat menselijker konden zien. Dat zou ik willen. En hoe ik dat moet doen; Joost mag het weten.' Dit brengt mij bij een andere interpretatie van het begrip relational restoration. Relationeel herstel gaat volgens mij niet zozeer over 'herstel van de relatie', maar veeleer over 'herstel door relatie'. Met deze invalshoek dringt een andere vraag zich op: zouden we de rechtspraktijk zo kunnen inrichten dat deze ongevalsbetrokkenen geholpen worden in hun zoektocht naar relationeel herstel?

\section{Per ongeluk verbonden}

Een verkeersslachtoffer en zijn ongevalsveroorzaker zijn letterlijk en figuurlijk 'per ongeluk verbonden'. In die notie ligt volgens mij een belangrijke kiem voor herstel van beide ongevalsbetrokkenen. Zij zijn gebaat bij verbindend aansprakelijkheidsrecht, dat de relatie tussen slachtoffer en veroorzaker inzet als middel naar herstel voor de individuele ongevalsbetrokkenen. Deze relationele kijk op de civiele verkeersaansprakelijkheid is bepaald niet gebruikelijk en ik realiseer mij ook dat tussen droom en daad op zijn minst nog vele praktische bezwaren liggen, voordat we echt kunnen spreken van verbindend aansprakelijkheidsrecht. Maar van mij mag het vonkje van restorative justice, dat in het strafrecht steeds meer

2 S. Cocquyt, Mij overkomt het niet. Ontmoetingen met veroorzakers van verkeersongevallen, Antwerpen: EPO Uitgeverij 2010, p. 55. Dit themanummer bevat een interview met Sabine Cocquyt over haar recent verschenen boek Het spijt mij - over bemiddeling na een verkeersongeval, Antwerpen: EPO Uitgeverij 2019. 
aangewakkerd wordt, ook overslaan naar de letselschadepraktijk. ${ }^{3}$ Opdat zij die per ongeluk verbonden raakten beter in staat worden gesteld om samen te zoeken naar passende vormen van verantwoording en herstel; met vuist én uitgestoken hand. En wie weet is dan het verkeersaansprakelijkheidsrecht van de toekomst niet alleen vergeldend en vergoedend, maar tegelijkertijd ook verbindend.

3 In de letselschadepraktijk zijn overigens wel elementen terug te vinden die sterk verwant zijn aan restorative justice. Zo werd bijvoorbeeld onderzoek gedaan naar het bevorderen door verzekeraars van het aanbieden van excuses aan verkeersslachtoffers (J.E. Hulst, A.J. Akkermans \& S. van Buschbach, Excuses aan verkeersslachtoffers, PIV-rapport, Den Haag: Boom Lemma uitgevers 2014). Veelbelovend is overigens ook dat de principes van restorative justice langzaam wel hun weg lijken te vinden naar de wereld van medische aansprakelijkheid. Zie B.S. Laarman, Just culture en Restorative justice in de afwikkeling van medische schade. Tijdschrift voor Vergoeding Personenschade 2019, nr. 3, p. 65-83. 